\title{
Leprosy Disabilities in the New Hebrides
}

\author{
L. L. BRAVO* and R. C. RATARD $\dagger$ \\ * WHO Leprologist, and + Chief Medical Officer, \\ Rural Health Service, Vila, New Hebrides
}

\begin{abstract}
The proportion of disabled among leprosy patients is $39 \%$ in the New Hebrides. This proportion is higher among lepromatous cases $(67 \%)$ than among tuberculoid and borderline cases (38\%). The disability index is higher among disabled lepromatous (1.2) than among disabled tuberculoid and borderline (0.8). Males are more often disabled than females ( $47 \%$ for males, $33 \%$ for females), but females seem to be more seriously disabled than males. There is an increase in the proportion of disabled and in the disability index with age. Disabilities are more frequent among positive cases, among patients taking irregular treatment or no treatment at all and among patients with leprae reaction. The proportion of disabled among tuberculoid cases increases 4 to 6 years after diagnosis and then decreases. For lepromatous patients there is a high and stable proportion of disabled from the beginning of the disease; there is also a steady increase in the severity of the disabilities. The nature of the initial symptoms influences the future occurrence of disabilities among tuberculoid and borderline cases. Only 13 to $16 \%$ will develop disabilities if there is no nerve involvement, 35 to $38 \%$ will do so if nerves are already involved. Bilateral lesions are more common among lepromatous than among tuberculoid or borderline cases. The prevalence of disabled for the whole population was estimated to be 2.7 per thousand.
\end{abstract}

\section{Introduction}

The Second Report of the WHO Expert Committee on Leprosy (WHO, 1960) estimated that about $25 \%$ of all leprosy patients have some degreee of disability. This figure was later considered as an underestimation of the disability problem at the Scientific Meeting on Rehabilitation in Leprosy (WHO, 1961), held at Vellore, India, in 1960 because "in many surveys anaesthesia of the hands and feet, which constitute severe disability, has not been recorded except when accompanied by deformity".

Percentages of disabled leprosy patients from different countries vary widely, as do the criteria for their classification and definition: $26.6 \%$ in Burma, $40.3 \%$ in Taiwan, $25.8 \%$ in Japan (Intl. Soc. Rehab. Lep., 1965), 42.9\% in South India (Rao, 1970).

Studies on prevalence of leprosy disabilities in different countries (Martinez Dominguez and Bechelli, 1966) and studies of disabilities in relation with other factors as sulphone treatment (Wardekar, 1968), socio-economic problems (Frist, 1973), etc., have been done using once again different criteria for the definition and evaluation of disabilities.

The writers assess the disability problem among the New Hebridean leprosy patients from the epidemiological and clinical points of view, evaluating the different factors that could influence the development of disabilities. The estimated prevalence of disabled leprosy patients for the whole country is also given. 
The following objectives have been chosen:

(1) The problem of leprosy disabilities in relation with the whole population (prevalence).

(2) Distribution of disabilities by sex, age, and type of leprosy.

(3) The relation between disabilities and bacteriological results, regularity of treatment and lepra reaction.

(4) The evaluation of disabilities with time.

(5) Prognosis of disabilities according to the initial lesions (skin, nerve, or both).

(6) Frequency of type of disability.

(7) Distribution of hand and foot disability according to the leprosy type (laterality of disabilities).

(8) Geographical distribution of disabilities in the group of islands and possible reasons for this.

\section{Material and Methods}

The data on disabled patients were collected from the clinical examinations made during leprosy surveys and periodic follow-ups.

Data on previous disabilities, initial symptoms, bacteriology and regularity of treatment were collected from the central register of the leprosy control unit of the New Hebrides.

The WHO form (WHO, 1970) for the recording of disabilities and the Disability Index DI-2 (Bechelli, 1971) was used because it is the most elaborated.

To describe the disability situation in any given group 2 data are presented:

(1) percentage of disabled;

(2) mean disability index of disabled patients.

\section{Results}

\section{FREQUENCY OF DISABILITIES}

Out of a total number of 700 leprosy patients alive in the New Hebrides, detailed data were available for 329 patients studied for disabilities. Among these, $128(39 \%)$ were found to suffer from some kind of disability. In comparison with other countries this percentage of disabled among leprosy patients is rather high. From this it may be estimated that there are about 270 disabled leprosy patients in the country, i.e. a prevalence rate of 2.7 per 1000 .

\section{DISABILITIES IN RELATION TO THE TYPE OF LEPROSY}

The data are presented in Tables 1 and 3 and Figs 3 and 4. No disabled were found among indeterminate cases. According to the WHO Classification for Disabilities (Bechelli, 1971), indeterminate cases have disabilities only if at least anaesthesia was present on hands or feet. Anaesthesia of indeterminate macules located elsewhere in the body is not considered as a disability. Among the other types there were:

(a) a higher percentage of disabled among lepromatous (67\%) than among tuberculoid and borderline $(38 \%)$ (difference significant at $P=0.05$ );

(b) a higher disability index among disabled lepromatous (1.2) than among disabled tuberculoid and borderline (0.8) (difference significant at $P=0.05$ ).

High percentages of disabled and high disability indices among lepromatous cases were also found in other studies (Martinez Dominguez and Bechelli, 1966; Novreen and Srinivasan, 1966). It can be explained by the widespread and progressive nature of lepromatous leprosy. The other types are more localized and have a shorter evolution.

The observations made on the tuberculoid and borderline groups were similar regarding the disabilities. Most of the boderline cases examined were close to the tuberculoid pole.

\section{DISABILITIES ACCORDING TO SEX}

The data are presented in Tables 1 and 2 and Figs 1 and 2. Males are more often disabled than females ( $47 \%$ for adult males, $33 \%$ for adult females; difference significant at $P=0.05$ ). 
TABLE 1

Disabilities by sex, age and leprosy types

\begin{tabular}{|c|c|c|c|c|c|c|c|c|c|c|c|c|c|c|c|c|}
\hline & \multicolumn{4}{|c|}{ Males } & \multicolumn{4}{|c|}{ Females } & \multicolumn{4}{|c|}{ Children } & \multicolumn{4}{|c|}{ Total } \\
\hline & $\begin{array}{l}\text { No. of } \\
\text { cases }\end{array}$ & $\begin{array}{l}\text { No. of } \\
\text { disabled }\end{array}$ & $\begin{array}{c}\% \\
\text { disabled }\end{array}$ & D.I. & $\begin{array}{l}\text { No. of } \\
\text { cases }\end{array}$ & $\begin{array}{c}\text { No. of } \\
\text { disabled }\end{array}$ & $\begin{array}{c}\% \\
\text { disabled }\end{array}$ & D.I. & $\begin{array}{l}\text { No. of } \\
\text { cases }\end{array}$ & $\begin{array}{c}\text { No. of } \\
\text { disabled }\end{array}$ & $\begin{array}{c}\% \\
\text { disabled }\end{array}$ & D.I. & $\begin{array}{l}\text { No. of } \\
\text { cases }\end{array}$ & $\begin{array}{l}\text { No. of } \\
\text { disabled }\end{array}$ & $\begin{array}{c}\% \\
\text { disabled }\end{array}$ & D.I. \\
\hline Indeterminate & 14 & 0 & 0 & - & 9 & 0 & 0 & - & 8 & 0 & 0 & - & 31 & 0 & 0 & - \\
\hline Tuberculoid & 77 & 36 & 47 & 0.7 & 61 & 20 & 33 & 0.9 & 26 & 5 & 19 & 0.4 & 164 & 61 & 37 & 0.8 \\
\hline Borderline & 62 & 26 & 42 & 0.8 & 22 & 8 & 36 & 0.8 & 4 & 2 & 50 & 0.2 & 88 & 36 & 41 & 0.8 \\
\hline Lepromatous & 31 & 24 & 77 & 1.0 & 15 & 7 & 47 & 2.4 & 0 & 0 & - & - & 46 & 31 & 67 & 1.2 \\
\hline Total & 184 & 86 & 471 & 0.8 & 107 & 35 & 33 & 1.1 & 38 & 7 & 18 & 0.3 & 329 & 128 & 39 & 0.8 \\
\hline
\end{tabular}

D.I., Disability Index. 
TABLE 2

Disabilities by age and sex

\begin{tabular}{|c|c|c|c|c|c|c|c|c|c|c|c|c|c|}
\hline & & \multicolumn{4}{|c|}{ Males } & \multicolumn{4}{|c|}{ Females } & \multicolumn{4}{|c|}{ Total } \\
\hline & & $\begin{array}{l}\text { No. of } \\
\text { cases }\end{array}$ & $\begin{array}{c}\text { No. } \\
\text { disabled }\end{array}$ & $\begin{array}{c}\% \\
\text { disabled }\end{array}$ & D.I. & $\begin{array}{l}\text { No. of } \\
\text { cases }\end{array}$ & $\begin{array}{c}\text { No. } \\
\text { disabled }\end{array}$ & $\begin{array}{c}\% \\
\text { disabled }\end{array}$ & D.I. & $\begin{array}{l}\text { No. of } \\
\text { cases }\end{array}$ & $\begin{array}{c}\text { No. } \\
\text { disabled }\end{array}$ & $\begin{array}{c}\% \\
\text { disabled }\end{array}$ & D.I. \\
\hline & $0-14$ & 16 & 5 & 31 & 0.3 & 22 & 2 & 9 & 0.3 & 38 & 7 & 18 & 0.3 \\
\hline & $(15-29$ & 82 & 28 & 34 & 0.7 & 48 & 14 & 29 & 0.7 & 130 & 42 & 32 & 0.7 \\
\hline \multirow{3}{*}{ Adults } & $30-44$ & 59 & 30 & 51 & 0.9 & 31 & 9 & 29 & 1.4 & 90 & 39 & 43 & 1.0 \\
\hline & $45+$ & 43 & 28 & 65 & 0.9 & 28 & 12 & 43 & 1.4 & 71 & 40 & 57 & 1.0 \\
\hline & $\begin{array}{l}\text { Sub- } \\
\text { total }\end{array}$ & 184 & 86 & 47 & 0.8 & 107 & 35 & 33 & 1.1 & 291 & 121 & 41 & 0.9 \\
\hline Total & & 200 & 91 & 45 & 0.8 & 129 & 37 & 29 & 1.1 & 329 & 128 & 39 & 0.9 \\
\hline
\end{tabular}




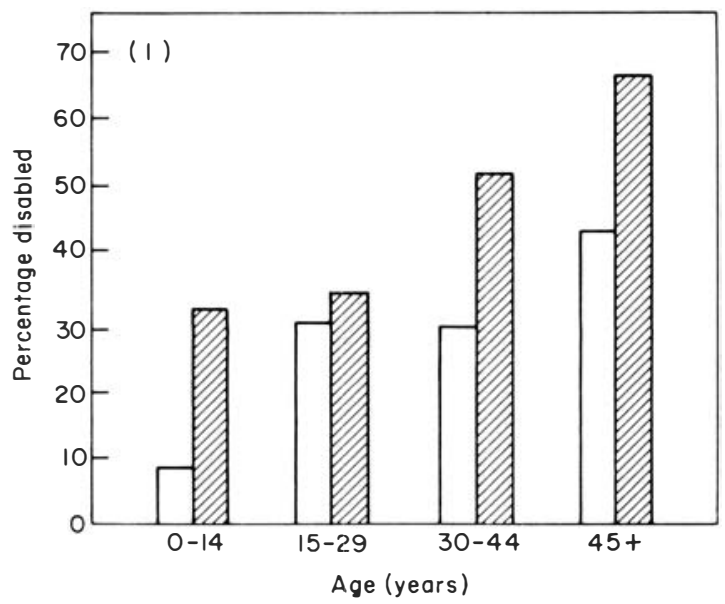

Fig. 1. Percentage of disabled according to age and sex; (घ) male; ( $\square$ ) female.

The same difference is observed in each type of leprosy, but it is more evident in the lepromatous type.

Although less often disabled, females seem to be more seriously disabled (D.I. $=0.8$ for males, 1.1 for females, difference not significant at $P=0.05)$. This difference is most prominent for the lepromatous type (D.I. $=1.0$ for males, 2.4 for females).

It is difficult to find a full explanation of these differences according to sex. Leprosy in the New Hebrides is almost entirely limited to the rural areas (only 2 cases were detected in the urban population). New Hebrideans are farmers, both the males and the females. Males spend more time working in gardens, hence a greater exposure to traumas of gardening and a higher proportion of disabled. Females do the easier gardening jobs along with housework and cooking. While cooking they are exposed to more severe disabilities. Male children have rougher activities than females.

It is not fully understood why there should be a difference between male and female lepromatous D.I. (0.8 versus 1.4$)$ and no difference between male and female tuberculoid or borderline (0.8 versus 0.8$)$.

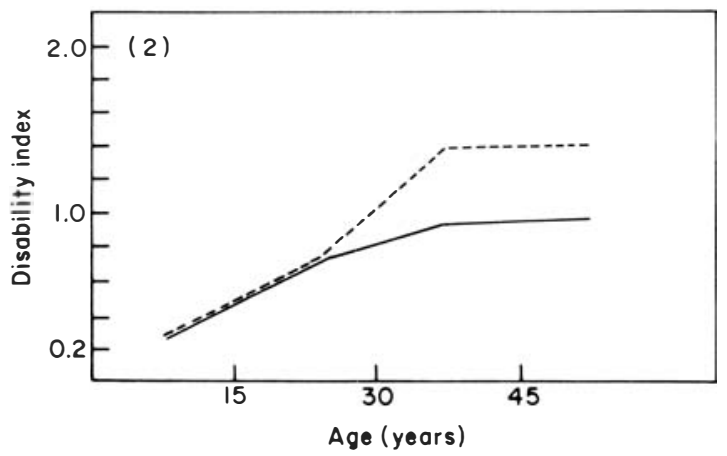

Fig. 2. Disability index according to age and sex. (----) male; (- - ) female. 
TABLE 3

Disabilities by age and leprosy type

\begin{tabular}{|c|c|c|c|c|c|c|c|c|c|c|c|c|c|}
\hline & & \multicolumn{4}{|c|}{ Tuberculoid } & \multicolumn{4}{|c|}{ Borderline } & \multicolumn{4}{|c|}{ Lepromatous } \\
\hline & & $\begin{array}{l}\text { No. of } \\
\text { cases }\end{array}$ & $\begin{array}{c}\text { No. } \\
\text { disabled }\end{array}$ & $\begin{array}{c}\% \\
\text { disabled }\end{array}$ & D.I. & $\begin{array}{l}\text { No. of } \\
\text { cases }\end{array}$ & $\begin{array}{c}\text { No. } \\
\text { disabled }\end{array}$ & $\begin{array}{c}\% \\
\text { disabled }\end{array}$ & D.I. & $\begin{array}{l}\text { No. of } \\
\text { cases }\end{array}$ & $\begin{array}{c}\text { No. } \\
\text { disabled }\end{array}$ & $\begin{array}{c}\% \\
\text { disabled }\end{array}$ & D.I. \\
\hline & $0-14$ & 26 & 5 & 19 & 0.4 & 4 & 2 & 50 & 0.2 & 0 & 0 & - & - \\
\hline & $(15-29$ & 61 & 22 & 38 & 0.5 & 41 & 16 & 39 & 0.9 & 11 & 4 & 36 & 0.8 \\
\hline & $30-44$ & 48 & 21 & 44 & 0.9 & 21 & 6 & 29 & 0.8 & 17 & 12 & 71 & 1.2 \\
\hline \multirow[t]{2}{*}{ Adults } & $\{45+$ & 29 & 12 & 41 & 1.1 & 22 & 12 & 54 & 0.7 & 18 & 15 & 83 & 1.4 \\
\hline & Sub- & 138 & 56 & 41 & 0.8 & 84 & 34 & 40 & 0.8 & 46 & 31 & 67 & 1.2 \\
\hline Total & & 164 & 61 & 37 & 0.8 & 88 & 36 & 41 & 0.8 & 46 & 31 & 67 & 1.2 \\
\hline
\end{tabular}




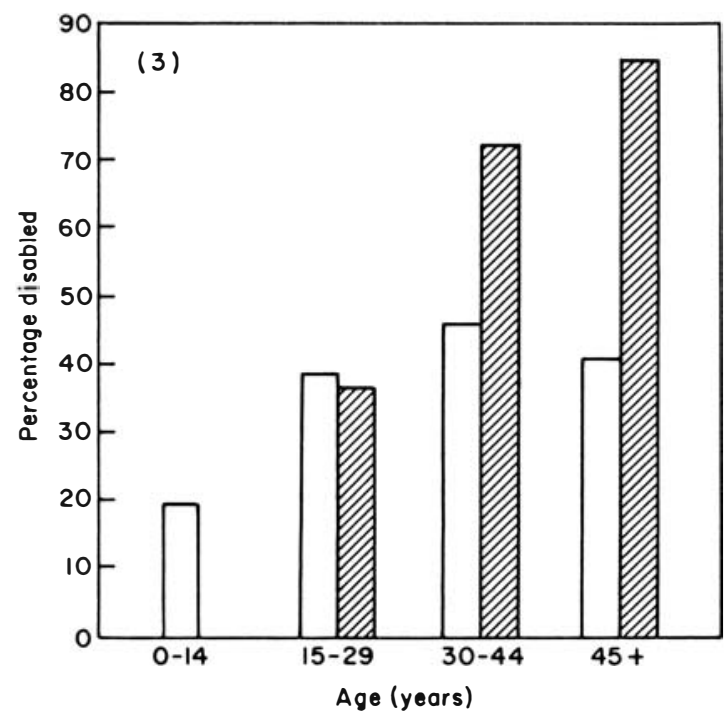

Fig. 3. Percentage of disabled according to age and leprosy type. (छ) LEP; ( $\square$ ) TUB.

\section{DISABILITIES AND AGE}

The breakdown by age groups of 15 years is presented in Tables 2 and 3 and Figs 2 and 3. For males and females, for tuberculoid, borderline and lepromatous there is a n increase of the percentage of disabled and of the disability index with age.

For tuberculoid and borderline the increase is progressive. The disabilities become more common and more serious with age. For the lepromatous the increase is very rapid until a high plateau is reached at the age of 30 . (It will be noted that the samples used are small.)

Males have more disabilities than females in all age groups. In the age group 0 to $14,31 \%$ of the males are already disabled while only $9 \%$ of the females show some disability. This difference is less conspicuous in the 15 to 29 years age group (34\% for males, $29 \%$ for females), but it becomes more obvious in the older age groups. Since there was no random sampling done, the smaller difference in the 15 to 29 age group might be due to random fluctuations.

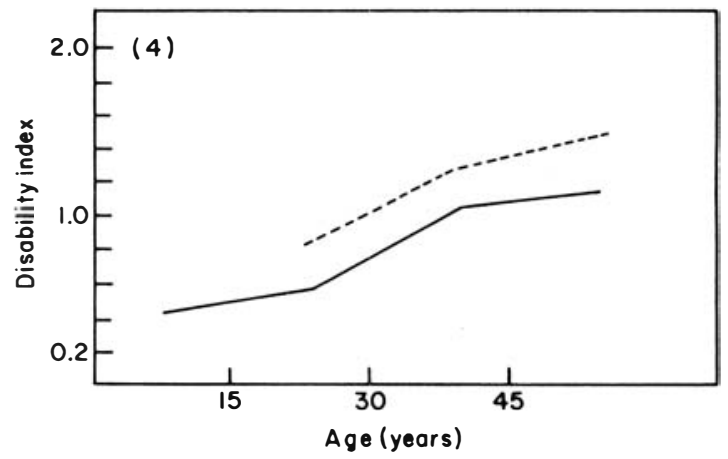

Fig. 4. Disability index according to age and leprosy type. (---) TUB; (- - -) LEP. 
The percentage of disabled children is high (18\%) in comparison with some other countries (Martinez Dominguez and Bechelli, 1966). There were no lepromatous cases in the age group below 15, hence this high percentage is observed among tuberculoid and borderline, mostly among males. It is likely that this diagnosis was made in relatively advanced stages of the disease.

\section{DISABILITIES AND BACTERIOLOGY}

The bacteriological status (Table 4) of the tuberculoid and borderline types influences the disability problem. There are more disabled among positive cases than among negative cases (67\% and $68 \%$ versus $41 \%$ and $38 \%$, differences significant at $P=0.05$ ). However it does not influence the severity of disability since disability indices are equivalent.

TABLE 4

Relation between disabilities and bacteriology

\begin{tabular}{lcccccccc}
\hline & \multicolumn{4}{c}{ Positive } & \multicolumn{4}{c}{ Negative } \\
& $\begin{array}{c}\text { No. of } \\
\text { cases }\end{array}$ & $\begin{array}{c}\text { No. } \\
\text { disabled disabled }\end{array}$ & D.I. & $\begin{array}{c}\text { No. of } \\
\text { cases }\end{array}$ & $\begin{array}{c}\text { No. } \\
\text { disabled disabled }\end{array}$ & D.I. \\
\hline Tuberculoid & 9 & 6 & 67 & 0.8 & 132 & 54 & 41 & 0.6 \\
Borderline & 25 & 17 & 68 & 0.8 & 77 & 29 & 38 & 0.7 \\
Total & 34 & 23 & 68 & 0.8 & 209 & 83 & 40 & 0.6 \\
\hline
\end{tabular}

TABLE 5

Geographical distribution of disabilities

\begin{tabular}{lcccc}
\hline \multicolumn{1}{c}{ Island } & $\begin{array}{c}\text { No. of cases } \\
\text { studied }\end{array}$ & $\begin{array}{c}\text { No. } \\
\text { disabled }\end{array}$ & $\begin{array}{c}\% \\
\text { disabled }\end{array}$ & D.I. \\
\hline Mota Lava & 37 & 13 & 35 & 1.7 \\
Vanua Lava & 9 & 1 & 11 & 0.3 \\
Mota & 11 & 2 & 18 & 0.2 \\
Other Banks/Torres & 11 & 6 & 54 & 0.8 \\
N. Santo & 24 & 15 & 62 & 0.5 \\
S. Santo & 63 & 21 & 33 & 0.6 \\
W. Santo & 10 & 8 & 80 & 1.2 \\
Islets & 9 & 2 & 22 & 0.4 \\
Aoba & 20 & 8 & 40 & 0.9 \\
Maewo-Malekula & 4 & 4 & 100 & 0.7 \\
Pentecost & 21 & 8 & 38 & 1.6 \\
Ambrym & 28 & 6 & 21 & 0.7 \\
Paama & 30 & 12 & 40 & 0.8 \\
Epi & 16 & 4 & 25 & 1.2 \\
CD1 Islets & 9 & 7 & 78 & 0.9 \\
Tanna & 24 & 9 & 37 & 0.8 \\
Sthn. Islets & 3 & 2 & 67 & 1.0 \\
Total & 329 & 128 & 39 & 0.8 \\
\hline
\end{tabular}

The geographical difference in the percentage of the disabled among leprosy patients is not significant. However the disabilities are not evenly distributed throughout the group of islands. There are several factors which are thought to influence this distribution by islands: quantity and quality of health posts available; means of communications; proportion of lepromatous; etc. For instance, in Mota Lava the severity of the disability problem (35\% of disabled, 


(5) \begin{tabular}{cc}
\cline { 2 - 2 } Indices & Number \\
\hline $0.1-0.3$ & 38 \\
$0.4-0.6$ & 15 \\
$0.7-0.9$ & 27 \\
$1.0-1.2$ & 18 \\
$1.3-1.5$ & 11 \\
$1.6-1.8$ & 7 \\
$1.9-2.1$ & 2 \\
$2.2-2.4$ & 2 \\
$2.5-2.7$ & 2 \\
$2.8-3.0$ & 1 \\
Over & 5 \\
\hline
\end{tabular}

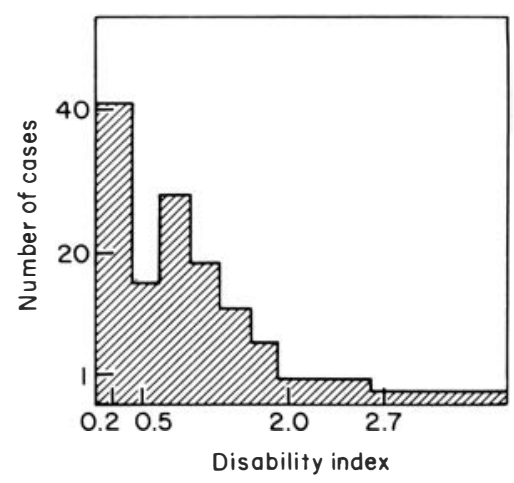

Fig. 5. Distribution of disability indices.

D.I. $=1.7)$ is probably due to the high prevalence of lepromatous on the island. In West Santo, the main contributing factors to the disabilities are the isolation and the complete lack of adequate facilities and trained personnel.

There is an apparent correlation between the percentage of disabled and the disability index: the higher the percentage of disabled, the higher the disability index. However, in 3 areas the disability index is higher than expected: Mota Lava, Epi and Pentecost islands. There is no obvious explanation for this lack of correlation.

\section{CLINICAL DESCRIPTION}

Out of 128 disabled patients, $41(32 \%)$ had only anaesthesia of hands and/or feet and 87 $(68 \%)$ had disabilities besides anaesthesia.

The majority of disabilities are minor ones as shown by Fig. 5. The different types of disabilities, anaesthesia excluded, are presented in Table 6. The most common disabilities are

TABLE 6

Types of disabilities

\begin{tabular}{llrr}
\hline & & Number & $\%$ \\
\hline Anaesthesia only & 41 & 32 \\
Anaesthesia \& deformity & 87 & 68 \\
Total & & 128 & 100 \\
Hand & Ulcer \& injuries & 8 & 4 \\
& Mobile claw & 54 & 28 \\
& Slight absorption & 36 & 19 \\
& Stiff joint & 4 & 2 \\
& Severe absorption & 10 & 5 \\
Feet & Ulcers & 45 & 23 \\
& Clawed toes & 6 & 3 \\
& Slight absorption & 10 & 5 \\
& Foot drop & 3 & 1.5 \\
& Contractures & 1 & 0.5 \\
& Severe absorption & 10 & 5 \\
Face & Lagophthalmos & 1 & 0.5 \\
& Iritis, keratitis & 3 & 0.5 \\
& Visual impairment & 3 & 1.5 \\
& Facial paralysis & 1 & 0.5 \\
\hline
\end{tabular}


TABLE 7

Hand and foot disability according to leprosy type

\begin{tabular}{lrccccccccc}
\hline & \multicolumn{1}{c}{$\begin{array}{c}\text { No. of } \\
\text { cases }\end{array}$} & $\begin{array}{c}\text { No. } \\
\text { disabled* }\end{array}$ & $\begin{array}{c}\text { No. with hand } \\
\text { disability }\end{array}$ & Monolateral & Bilateral & $\begin{array}{c}\% \\
\text { bilateral }\end{array}$ & $\begin{array}{c}\text { No. with foot } \\
\text { disability }\end{array}$ & Monolateral & bilateral & $\begin{array}{c}\% \\
\text { bilateral }\end{array}$ \\
\hline Tuberculoid & 164 & 61 & 38 & 28 & 10 & 26.3 & 25 & 21 & 4 \\
Borderline & 88 & 36 & 18 & 15 & 3 & 16.7 & 18 & 16.0 \\
Lepromatous & 46 & 31 & 16 & 5 & 11 & 68.7 & 17 & 6 & 11 & 64.7 \\
\hline
\end{tabular}

* Some cases had both hand and foot disabilities.

TABLE 8

Prognosis of disabilities according to the initial lesions

\begin{tabular}{|c|c|c|c|c|c|c|c|c|c|c|c|c|}
\hline & \multicolumn{4}{|c|}{ Skin only } & \multicolumn{4}{|c|}{ Nerve only } & \multicolumn{4}{|c|}{ Both involved } \\
\hline & $\begin{array}{l}\text { No. of } \\
\text { cases }\end{array}$ & $\begin{array}{l}\text { No. } \\
\text { disabled }\end{array}$ & $\begin{array}{c}\% \\
\text { disabled }\end{array}$ & D.I. & $\begin{array}{l}\text { No. of } \\
\text { cases }\end{array}$ & $\begin{array}{c}\text { No. } \\
\text { disabled }\end{array}$ & $\begin{array}{c}\% \\
\text { disabled }\end{array}$ & D.I. & $\begin{array}{l}\text { No. of } \\
\text { cases }\end{array}$ & $\begin{array}{c}\text { No. } \\
\text { disabled }\end{array}$ & $\begin{array}{c}\% \\
\text { disabled }\end{array}$ & D.I. \\
\hline Tuberculoid & 73 & 12 & 16 & 0.2 & 21 & 8 & 38 & 0.2 & 22 & 8 & 36 & 0.5 \\
\hline Borderline & 61 & 8 & 13 & 0.1 & 4 & 0 & 0 & - & 20 & 7 & 35 & 0.3 \\
\hline Lepromatous & 13 & 7 & 54 & 0.8 & 0 & - & - & - & 9 & 5 & 56 & 1.3 \\
\hline Total & 147 & 27 & 18 & 0.5 & 25 & 8 & 32 & 0.2 & 51 & 20 & 39 & 0.7 \\
\hline
\end{tabular}


(6)
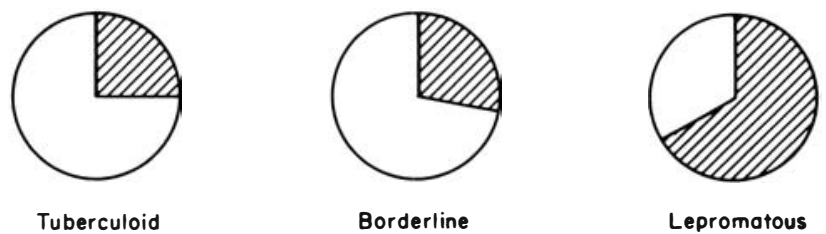

Fig. 6. Laterality of disabilities of hands and feet. ( $) \%$ of bilateral lesions.

the mobile claw hand which represents $28 \%$ of all disabilities, foot ulcers with $23 \%$ and hand absorption at $19 \%$.

Bilateral lesions are significantly more common among lepromatous than borderline or tuberculoid (Table 7 and Fig. 6). Looking at the distribution of the clinical lesions, the patients classified as borderline are, in the New Hebrides, close to the tuberculoid pole. The distribution of disabilities follows the pattern observed for skin and nerve lesions. The disabilities are localized and asymmetrical in the tuberculoid and widespread and symmetrical in the lepromatous.

Lepra reaction provokes the development of disabilities. For 14 lepromatous cases who had had lepra reaction in the past, the disability index was 1.4 . It is only 0.8 among all other lepromatous cases. However the number of cases is too small to provide more detailed information.

\section{EVOLUTION OF THE DISABILITIES}

Data regarding initial symptoms were available for 223 cases.

The nature of the initial symptoms (skin symptoms, nerve symptoms, or both) influence the future occurrence of disabilities among tuberculoids and borderline cases. Only $13 \%$ to $16 \%$ will develop disabilities if there is no nerve involvement, while $35 \%$ to $38 \%$ will do so if nerves are involved (Table 8).

The evolution of disabilities with time is presented in Table 9 and Figs 6 and 7. For tuberculoid patients the proportion of disabled increases 4 to 6 years after diagnosis and then decreases. The severity of these disabilities is fairly constant (stable index). For lepromatous patients there is a high and stable proportion of disabled with a steady increase of the severity of the disability. The improvement of disabilities of tuberculoid patients may be due to the recovery of Grade 1 disabilities (anaesthesia only, in hands and/or feet, conjunctivitis). Among lepromatous patients Grade 1 disabilities appear at a later stage and the disabilities get worse.

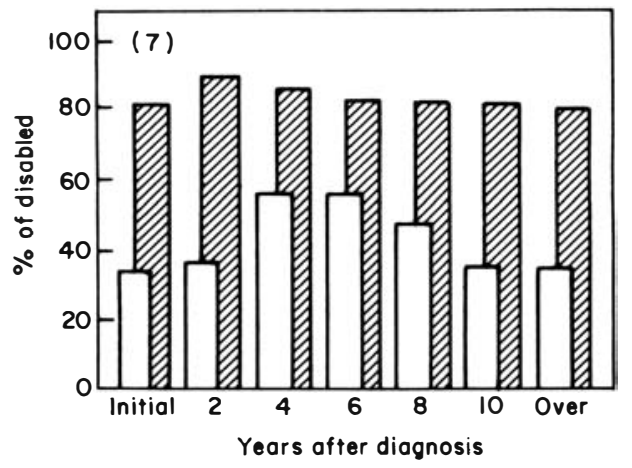

Fig. 7. Evolution of disabilities with time. (『) LEP; (口) TUB. 


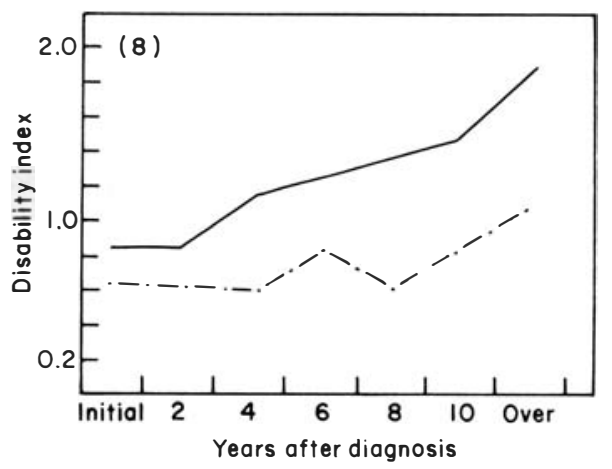

Fig. 8. Evolution of disability index with time. (---) LEP; (-.-.) TUB.

TABLE 9

Evolution of disabilities with time

\begin{tabular}{|c|c|c|c|c|c|c|c|c|}
\hline & & \multirow[b]{2}{*}{$\begin{array}{l}\text { Initial } \\
\text { exam. }\end{array}$} & \multicolumn{6}{|c|}{ Years after diagnosis } \\
\hline & & & 2 & 4 & 6 & 8 & 10 & Over \\
\hline $\mathrm{T}$ & $\begin{array}{l}\text { No. of patients } \\
\text { No. disabled } \\
\text { \% disabled } \\
\text { D.I. }\end{array}$ & $\begin{array}{c}92 \\
33 \\
36 \\
0.6\end{array}$ & $\begin{array}{c}49 \\
19 \\
39 \\
0.6\end{array}$ & $\begin{array}{c}17 \\
10 \\
59 \\
0.6\end{array}$ & $\begin{array}{c}17 \\
10 \\
59 \\
0.8\end{array}$ & $\begin{array}{r}19 \\
9 \\
47 \\
0.6\end{array}$ & $\begin{array}{c}20 \\
7 \\
35 \\
0.8\end{array}$ & $\begin{array}{c}20 \\
7 \\
35 \\
2.2\end{array}$ \\
\hline B & $\begin{array}{l}\text { No. of patients } \\
\text { No. disabled } \\
\% \text { disabled } \\
\text { D.I. }\end{array}$ & $\begin{array}{c}86 \\
26 \\
30 \\
0.9\end{array}$ & $\begin{array}{c}39 \\
12 \\
31 \\
1.1\end{array}$ & $\begin{array}{c}22 \\
12 \\
54 \\
1.4\end{array}$ & $\begin{array}{c}27 \\
16 \\
59 \\
1.1\end{array}$ & $\begin{array}{c}17 \\
9 \\
53 \\
1.2\end{array}$ & $\begin{array}{c}28 \\
11 \\
39 \\
1.1\end{array}$ & $\begin{array}{l}15 \\
10 \\
67 \\
1.1\end{array}$ \\
\hline $\mathrm{L}$ & $\begin{array}{l}\text { No. of patients } \\
\text { No. disabled } \\
\% \text { disabled } \\
\text { D.I. }\end{array}$ & $\begin{array}{c}27 \\
23 \\
85 \\
0.8\end{array}$ & $\begin{array}{c}23 \\
21 \\
91 \\
0.8\end{array}$ & $\begin{array}{c}18 \\
15 \\
83 \\
1.1\end{array}$ & $\begin{array}{c}12 \\
10 \\
83 \\
1.2\end{array}$ & $\begin{array}{c}14 \\
12 \\
86 \\
1.3\end{array}$ & $\begin{array}{c}12 \\
10 \\
83 \\
1.4\end{array}$ & $\begin{array}{l}22 \\
17 \\
77 \\
1.7\end{array}$ \\
\hline
\end{tabular}

TABLE 10

Relation between disabilities and regularity of treatment

\begin{tabular}{lcccccccc}
\hline & \multicolumn{4}{c}{ Regular } & \multicolumn{5}{c}{ None or irregular } \\
& $\begin{array}{l}\text { No. of } \\
\text { cases }\end{array}$ & $\begin{array}{c}\text { No. } \\
\text { disabled disabled }\end{array}$ & D.I. & $\begin{array}{c}\text { No. of } \\
\text { cases }\end{array}$ & $\begin{array}{c}\text { No. disabled disabled } \\
\text { disal }\end{array}$ & D.I. \\
\hline Tuberculoid & 11 & 7 & 64 & 0.5 & 39 & 22 & 56 & 0.6 \\
Borderline & 22 & 4 & 18 & 1.5 & 35 & 16 & 46 & 0.9 \\
Lepromatous & 10 & 7 & 70 & 1.2 & 11 & 11 & 100 & 1.5 \\
Total & 43 & 18 & 42 & 1.0 & 85 & 49 & 58 & 0.9 \\
\hline
\end{tabular}


Nerve and bone involvement in lepromatous leprosy are bound to occur and to cause disabilities even under treatment (Jopling, 1971).

The effects of the regularity of treatment on the percentage of disabled is significant in the lepromatous and borderline types (Table 10). Data were available for 128 patients. However, it is difficult to conclude that this is the effect of treatment as these cases were not randomly selected.

The lower percentage of disabled among regularly treated patients has already been mentioned (Wardekar, 1968). However, the opposite observation has also been made (Noordeen and Srinivasan, 1966). DDS in large doses may increase the incidence of lepra reaction, mostly in borderline patients, but this does not counterbalance the beneficial effects of the treatment.

\section{IMPORTANCE OF THE DISABILITY PROBLEM}

From the data collected in the sample of 329 patients studied, the prevalence of disabilities among the whole population may be estimated at 2.7 per thousand. The 700 presently living patients would have the following disabilities:

\begin{tabular}{llr}
\hline Unable to work & $($ D.I. $>3)$ & 10 \\
Partially disabled & $(1<$ D.I. $\leqslant 3)$ & 60 \\
Mild disability & $(0<$ D.I. $\leqslant 1)$ & 200 \\
No disability & (D.I. $=0)$ & 430 \\
\hline
\end{tabular}

This does not constitute an economic problem for the manpower of the country. There is also a very small social problem since prejudice against leprosy and/or its deformed victims is minimal. Disabled patients are looked after by their families or by the community.

\section{Conclusion}

Although the prevalence of leprosy is rather low in the New Hebrides (2.9 per 100) in comparison to other countries the prevalence of disabilities is rather high, probably due to late diagnosis. The isolation and difficulty of communications in this island group and the scarcity of well-trained medical personnel impair the early diagnosis of leprosy. The primitive living and working conditions contribute to the development of severe disabilities.

It would be justified for the leprosy control programme to put more emphasis on the detection and prevention of disabilities, with males and lepromatous being the groups which have higher risks. Females have less risk of developing disabilities, but the disabilities they do develop tend to be more severe. Case detection and health education could be better utilized after the results of this study.

\section{Acknowledgement}

Thanks are due to the World Health Organization for permission to publish this paper.

\section{References}

Bechelli, L. M. and Martinez-Dominguez, V. (1971). Disability index for leprosy patients Bull. Wld Hlth Org. 44, 709.

Frist, T. F. (1973). A developing country, leprosy control and the severely disabled. Lepr. Rev. $44,90$.

International Society for Rehabilitation of Disabled (1965). Papers on leprosy rehabilitation. Third Pan-Pacific Rehabilitation Conference, Tojyo, p. 29.

Jopling, W. H. (1971). Handbook of Leprosy. William Heineman Medical Books Ltd, London. Martinez-Dominguez, V., Bechelli, L. M. and Patwary, K. M. (1966). WHO surveys of disabilities in leprosy in Northern Nigeria (Katsina), Cameroon and Thailand (Khon Kaen). Int. J. Lepr. 34, 244. 
Noordeen, S. K. and Srinivasan, H. (1966). Epidemiology of disability in leprosy. 1. A general study of disability among male leprosy patients above fifteen years of age. Int. J. Lepr. $34,159$.

Rao, P. S. et al. (1970). Prevalence of deformities and disabilities among leprosy patients in an endemic area. Part I: General findings. Int. J. Lepr. 38, 1.

Srinivasan, H. and Noordeen, S. K. (1966). Epidemiology of disability in leprosy. 2. Factors associated with a low disability. Int. J. Lepr. 34, 170.

Wardekar, R. V. (1968). Sulfone treatment and deformity in leprosy. Lepr. in India 40, 161.

WHO (1960). Expert committee on leprosy. Wld. Hlth Org. Tech. Rep. Ser. 189.

WHO (1961). Scientific meeting on rehabiliation in leprosy. Wld. Hlth Org. Tech. Rep. Ser. 221.

WHO (1970). Expert committee on leprosy. Wld. Hlth Org. Tech. Rep. Ser. 459. 